\title{
АНАЛІЗ ВОДНИХ РЕСУРСІВ УКРАЇНИ В КОНТЕКСТІ МОЖЛИВОСТІ ЇХ ВИКОРИСТАННЯ ДЛЯ ВИРОБНИЦТВА «ЗЕЛЕНОГО» ВОДНЮ
}

\author{
К.В. Петренко, І.В. Іванченко, О.О. Кармазін, канд. техн. наук, ст. наук. співроб.
}

Інститут відновлюваної енергетики НАН України, 02094, вул. Гната Хоткевича, 20А, м. Київ, Україна

Мета статті - аналіз водних ресурсів України та з'ясування можливості їх використання для отримання «зеленого» водню. Розгортання сучасних водневих технологій для потреб енергетики України стає важливим напрямком. Застосування водню дасть значні переваги для енергетичної системи України, навколишнього середовища та бізнесу. Потениійно можливий обсяг виробництва «зеленого» водню в Украӥні за допомогою електролізу розраховано за результатами проведених наукових досліджень потенціалу генерації електроенергіі вітро- та фотоелектричними станціями. Для розрахунку потенційно можливого обсягу виробництва «зеленого» водню за допомогою електролізу передбачено питоме споживання електроенергії 4,5 кBm·год/нм $\mathrm{H}_{2}$. Потенціал середньорічного виробітку «зеленого» водню на території України становить 505132 млн нм³. Електроліз води на даний момент вважається найоптимальнішою технологією для отримання стійкого водню. Для виробнищтва 1 нм $\mathrm{H}_{2}$ використовується 1,5-2,0 л води, тобто для використання середньорічного потенціалу «зеленого» водню (505 132 млн нм³) потрібно 757,7 млн м води. Прогнозоване до 2030 року зменшення втрат води за рахунок удосконалення технологічних проиесів підйому, виробництва й транспортування води в результаті впровадження енергоефективних технологій, дозволяє на $70 \%$ задовольнити потребу у воді для використання всього наявного середньорічного потенціалу виробництва «зеленого» водню (518 млн м $\left.^{3}\right)$. Аналіз запасів нормативно очищених та нормативно чистих без очистки стічних вод (4 473 млн м³) показав перевищення в 6 разів потреби у воді для реалізації всього потенціалу «зеленого» водню. Для виробництва водню також може бути використана морська вода. Отже, наявні водні ресурси України є цүілком достатніми для повної реалізаџї потенціалу виробництва «зеленого» водню без збільщення водозабору. Бібл. 18, табл. 1, рис. 5.

Ключові слова: «зелений» водень, потенціал «зеленого» водню, водні ресурси, водозабір, втрати води, стічні води.

\section{ANALYSIS OF UKRAINE'S WATER RESOURCES IN THE CONTEXT OF THEIR USE POSSIBILITY FOR THE PRODUCTION OF "GREEN" HYDROGEN}

K. Petrenko, I. Ivanchenko, O. Karmazin, candidate of technical sciences, senior researcher

Institute of renewable energy, NAS Ukraine,

02094, 20A Hnata Khotkevycha St., Kyiv.

The purpose of the article is to analyze the water resources of Ukraine and find out the possibility of using them to obtain "green" hydrogen. Deployment of modern hydrogen technologies for the energy needs of Ukraine is becoming an important area. The use of hydrogen will provide significant benefits for Ukraine's energy system, environment and business. The potentially possible volume of "green" hydrogen production in Ukraine by electrolysis is calculated based on the results of scientific research on the potential of electricity generation by wind and solar plants. For the calculation of potential output "green" hydrogen via electrolysis provided specific power consumption of $4.5 \mathrm{~kW} \cdot h / n \mathrm{~m}^{3} \mathrm{H}_{2}$. The potential annual production of "green" hydrogen in Ukraine is 505,132 million $n^{3}$ per year. Electrolysis of water is currently considered the most optimal technology for obtaining stable hydrogen. 1.5-2.0 l of water is used to produce $1 \mathrm{n} \mathrm{m}^{3}$ of $\mathrm{H}_{2}$, so $757.7 \mathrm{million} \mathrm{m}^{3}$ of water is required to use the annual potential of "green" hydrogen per year (505.132 million $\mathrm{n} \mathrm{m}^{3}$ ). The projected reduction of water losses by 2030 due to the improvement of technological processes of lifting, production and transportation of water as a result of the introduction of energy efficient technologies, allows to meet $70 \%$ of water demand to use all available average annual production potential of "green" hydrogen per year (518 million $\left.\mathrm{m}^{3}\right)$. Analysis of stocks of normatively treated 
and normatively pure without wastewater treatment (4473 млн $\left.\mathrm{m}^{3}\right)$ showed a 6-fold excess of water demand for the realization of the full potential of "green" hydrogen. Seawater can also be used to produce hydrogen. Thus, the available water resources of Ukraine are quite sufficient to fully realize the potential of green hydrogen production without increasing the water intake. Ref. 18, table 1, fig. 5.

Keywords: "Green" hydrogen, the potential of "green" hydrogen, water resources, water intake, water loss, wastewater.

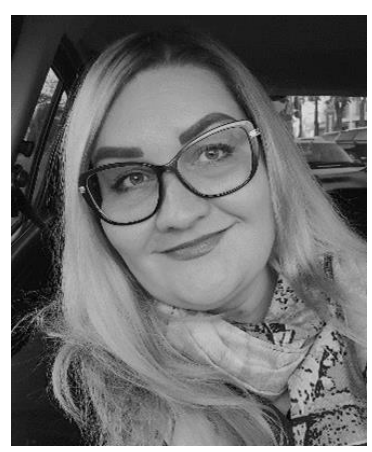

К.В. Петренко

K. Petrenko

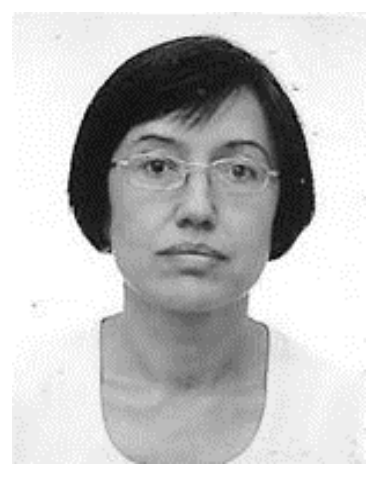

I.В. Іванченко

I. Ivanchenko

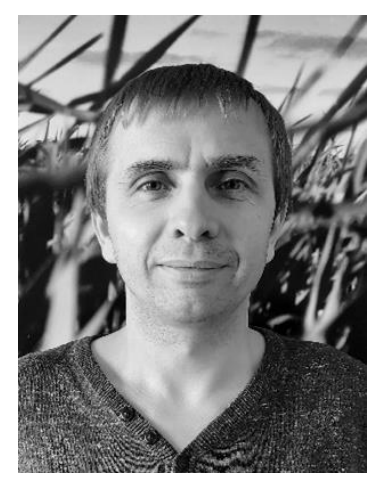

O.О. Кармазін

O. Karmazin
Відомості про автора: головний технолог відділу вітроенергетики Інституту відновлюваної енергетики НАН України, магістр метеорології та кліматології

Освіта: Київський національний університет імені Тараса Шевченка, географічний факультет, кафедра метеорології та кліматології

Наукова сфера: метеорологія, кліматологія, картографія, вітроенергетика

Публікації: 18

ORCID: 0000-0002-2322-9030

Контакти: тел. +38(067)129-07-43 e-mail: KaterynkaPetrenko@ gmail.com

Відомості про автора: головний технолог відділу вітроенергетики Інституту відновлюваної енергетики НАН України

Освіта: Київський національний університет технологій та дизайну, інженерно-економічний факультет Наукова сфера: вітроенергетика, оцінка вітроенергетичного потенціалу, економічна ефективність інвестицій в будівництво вітрових електростанцій

Публікації: 40

ORCID: 0000-0002-5083-4180

Контакти: тел./факс: +38(044)206-28-09 e-mail: $\underline{\text { mntcwind@gmail.com }}$

Відомості про автора: старший науковий співробітник відділу комплексних енергосистем Інституту відновлюваної енергетики НАН України Освіта: Національний технічний університет «Харківський політехнічний інститут», фізико-технічний факультет. Спеціальність «Нетрадиційні джерела енергії»

Наукова сфера: функціонування й паралельна робота різнотипних відновлюваних джерел енергії в електромережі

Публікації: 29

ORCID: 0000-0002-7628-6880

Контакти: +38(044)206-28-09

e-mail: alexey.karmazin@gmail.com
Author information: Chief technologist of Wind Energy Department, Institute of Renewable Energy of NAS of Ukraine, Master Degree (Meteorology and

Climatology)

Education: Taras Shevchenko National

University, Department of Meteorology and Climatology

Research area: Meteorology, Climatology,

Cartography, Wind Power

Publications: 18

ORCID: 0000-0002-2322-9030

Contacts: тел.: +38(067)129-07-43

e-mail: KaterynkaPetrenko@gmail.com

Author information: chief technologist at wind energy department at Institute of Renewable Energy of NAS of Ukraine Education: Kiev National University of Technology and Design, Faculty of Engineering and Economics

Research area: wind energy, assessment of wind energy potential, economic efficiency of investments in the construction of wind power plants

Publications: 40

ORCID: 0000-0002-5083-4180

Contacts: tel./fax: +38(044)206-28-09

e-mail: mntcwind@gmail.com

Author information: senior researcher of Department of Complex Power Systems of the Institute of Renewable Energy of the National Academy of Sciences of Ukraine Education: National Technical University

Kharkiv Polytechnic Institute, PhysicalTechnical Faculty, «Non-Conventional Sources of Energy»

Research area: operation and parallel operation of various types of renewable energy sources in the grid

Publications: 29

ORCID: 0000-0002-7628-6880

Contacts: +38(044)206-28-09

e-mail: alexey.karmazin@gmail.com

\section{Перелік використаних позначень та скорочень:}

ВДЕ - відновлювані джерела енергії;

ВЕС - вітрова електростанція;

СЕС - сонячна електростанція;

ОЕС - об'єднана енергосистема;
$\mathrm{CO}_{2}$ - вуглекислий газ;

$\mathrm{H}_{2}$ - водень;

1 нм$^{3}-1 \mathrm{~m}^{3}$ речовини за «нормальних умов» (тиск

760 мм рт. ст., що відповідає 101325 Па, і температура $0^{\circ} \mathrm{C}$ ); 
Вступ. Стан енергетики України характеризується прискореним зростанням частки ВДЕ в енергобалансі. Зокрема, за даними Держенергоефективності України, сукупна потужність встановлених вітрових і сонячних електростанцій в Україні на березень 2021 року становить 7,8 ГВт [13]. При цьому розроблені проєкти будівництва сягають десятків гігават потужностей лише ВЕС та СЕС, переважно сконцентрованих у південних регіонах. Сучасна енергосистема не здатна адекватно працювати при таких обсягах мінливої генерації, оскільки баланс потужності ОЕС України характеризується дефіцитом маневрених i регулювальних потужностей. Раціональним розв'язанням проблеми світова практика вважає застосування акумулювання енергіі 3 подальшим використанням іiї для забезпечення енергетичного балансу [3].

Розгортання сучасних водневих технологій для потреб енергетики України стає важливим напрямком, що передбачає використання водню як проміжного енергоносія для забезпечення збалансованого використання ВДЕ.

Ринок генерації водню оцінюється в 130 млрд дол. США у 2020 році і, як очікується, виросте до 201 млрд дол. США в 2025 році [2]. За прогнозом Hydrogen Council, 2017 використання водню дозволить до 2050 року забезпечити $18 \%$ загальної світової потреби в енергії, уникнути 6 Гт викидів $\mathrm{CO}_{2}$, забезпечити річний прибуток в 2,5 трлн доларів на ринку водневого й паливного обладнання та забезпечити стійку зайнятість для понад 30 млн людей [3].

Потенційно можливий обсяг виробництва «зеленого» водню в Україні розраховано за результатами проведених наукових досліджень потенціалу генерації електроенергії вітро- та фотоелектричними станціями. Для розрахунку потенційно можливого обсягу виробництва «зеленого» водню за допомогою електролізу передбачено питоме споживання електроенергії 4,5 кВт·год / нм ${ }^{3} \mathrm{H}_{2}$ або 50,56 кВт·год/кг $\mathrm{H}_{2}$. За результатами розрахунків, потенціал середньорічного виробітку «зеленого» водню на

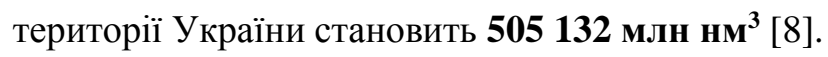

Електроліз води на даний момент вважається найоптимальнішою технологією для отримання стійкого водню. Ця технологія передбачає використання постійного електричного струму для поділу молекул води, в результаті чого утворюються водень та кисень [13]. Для виробництва $1 \mathrm{нm}^{3} \mathrm{H}_{2}$ використовується 1,5-2,0 л води [1] або 1,5-2,0 тис м ${ }^{3}$ води для виробництва 1 млн нм ${ }^{3} \mathrm{H}_{2}$. На основі даних потенціалів виробництва електроенергії по областях України відновлюваними джерелами (сонцем та вітром) [8] встановлено, що 3 урахуванням вказаної пропорції для використання всього потенціалу «зеленого» водню (505 132 млн нм ${ }^{3}$ ) потрібно 757,7 млн м $\mathbf{m}^{3}$ води (табл. 1).

Метою даної роботи $\epsilon$ аналіз водних ресурсів України та з'ясування можливості їх використання в процесі отримання «зеленого» водню.

Водні ресурси світу. Водні ресурси - це обсяги поверхневих, підземних і морських вод відповідної території [11].

Ресурси прісних вод складаються 3 так званих статичних (або вікових) запасів води i безперервно відновлюваних водних ресурсів. Статичні (вікові) запаси прісних вод представлені частинами водних об'ємів озер, льодовиків, підземних вод, які не підлягають щорічним змінам (поновлюються надзвичайно повільно, протягом сотень і тисяч років). Статичні запаси вод не можна вилучати на господарські потреби без завдання шкоди даним водним об'єктам або пов'язаним з ними річкам.

Відновлювані запаси прісних вод - це материковий стік у Світовий океан (річковий та підземний стік). Відновлювані водні ресурси оцінюють за допомогою рівняння водного балансу. В середньому на поверхнях материків 3 усієї суми атмосферних опадів на випаровування витрачається приблизно $61 \%$, а решта $39 \% 3$ материковим стоком (річковим та підземним) надходить у Світовий океан.

Здебільшого під відновлюваними водними ресурсами розуміють лише частину материкового стоку, яка представлена стоком річок 
(41,7 тис. км води на рік, або $35 \%$ атмосферних опадів на планеті). Тому з практичних позицій під водними ресурсами окремих держав чи регіонів розуміють лише величину середньорічного стоку річок [18].

За оцінкою [6], показник загальних відновлюваних водних ресурсів на душу населення в Україні становить $3035 \mathrm{~m}^{3}$ на рік, що ставить нас в один ряд 3 такими країнами як Італія (3210 м ${ }^{3}$ на рік), Молдова (3207 м² на рік), Туреччина (2890 м ${ }^{3}$ на рік) та Болгарія $\left(2805 \mathrm{~m}^{3}\right.$ на рік) (рис. 1).

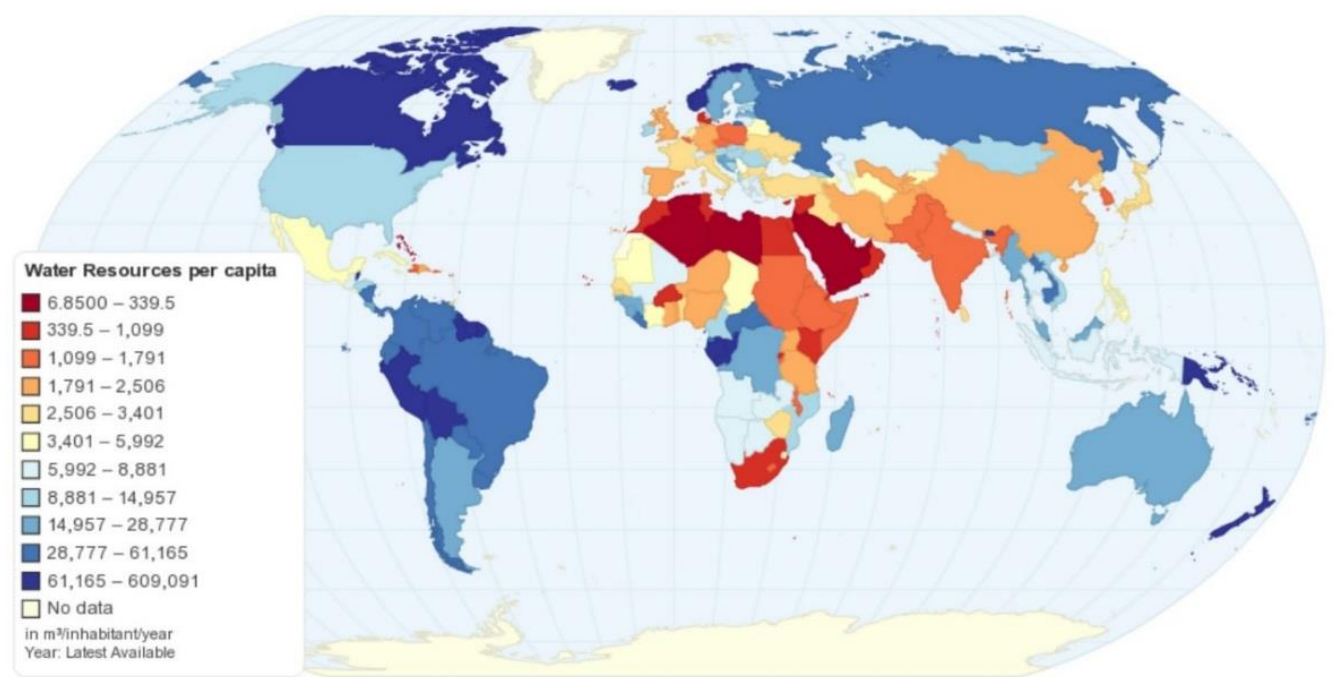

Рис. 1. Загальні відновлювані водні ресурси на душу населення по країнах світу [6]

Fig. 1. Total Renewable Water Resources per capita by Country [6]

Якщо виразити водовідбір (кількість води, гідрологічний цикл (загальні фактичні вилученої з доступних джерел для використання відновлювані водні ресурси), отримаємо показник людиною у сільському господарстві, побутовому використання відновлюваних водних ресурсів та промисловому секторах) у відсотках загального (рис. 2).

обсягу води, що доступна щороку через

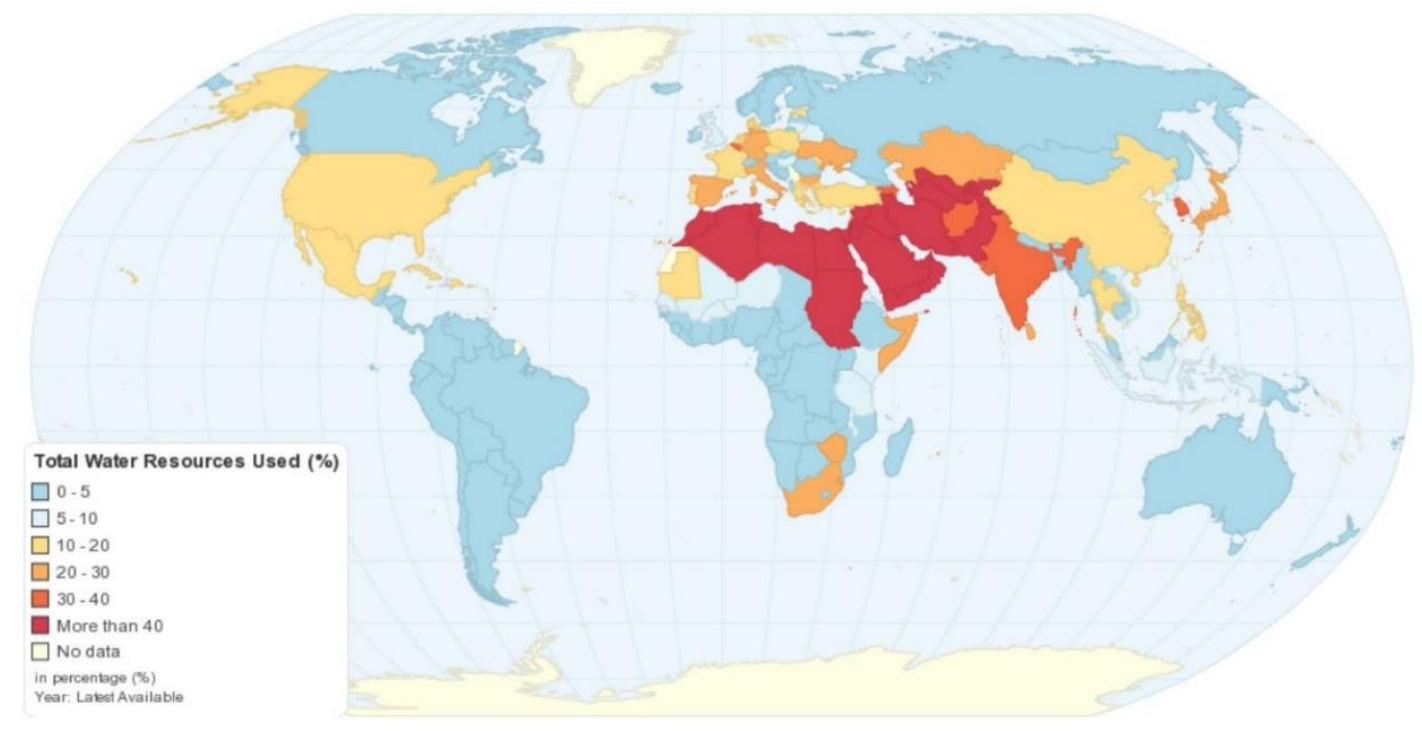

Рис. 2. Використання відновлюваних водних ресурсів (\%) [7]

Fig. 2. Proportion of Total Water Resources Used, percentage [7]. 
Для України цей показник становить $27,56 \%$ (для Болгарії - 28,73 \%, Італії - 23,69\%, Молдови - 16,44\%, Туреччини - $18,77 \%$, Польщі - 19,4 \%) [7].

Водні ресурси України. Усі поверхневі води України формують ії гідрографічну мережу, яка займає 242 тис. км² території держави, що складає близько 4 \% іiі загальної площі [12]. За загальним об'ємом відновлюваних водних ресурсів Україна посідає 56-те місце у світі 3 показником 139,5 км ${ }^{3}$ [7]. Відповідно до даної оцінки, у використанні всього потенціалу виробництва "зеленого" водню (для якого потрібно 0,758 км 3 води) було б задіяно 0,54 \% загальних відновлюваних водних ресурсів. Проте, відповідно до даних Продовольчої та сільськогосподарської організації $\mathrm{OOH}$, відновлювані внутрішні прісноводні ресурси на душу населення в Україні станом на 2014 рік становили $1217,09 \mathrm{M}^{3}$ [5], за цим показником Україна посідає 125-те місце у світі.

У 2019 році з природних джерел забрано 11111 млн м ${ }^{3}$ води (прісної - 10596 млн м³), 3 них 1157 млн м ${ }^{3}-3$ підземних водних джерел, у тому числі 318,3 млн м ${ }^{3}$ шахтно-кар'єрних вод. Найбільше води забрано у Дніпропетровській $\left(1180\right.$ млн м $\left.{ }^{3}\right), \quad$ Донецькій $\quad\left(1791\right.$ млн м $\left.{ }^{3}\right)$, Запорізькій $\quad\left(1198\right.$ млн м $\left.{ }^{3}\right), \quad$ Херсонській $\left(2614\right.$ млн м $\left.{ }^{3}\right)$, Одеській (866,5 млн м ${ }^{3}$ ) областях та у м. Києві $\left(710,8\right.$ млн м $\left.{ }^{3}\right)$, на які припадає $75 \%$ сумарного обсягу забору води. У басейновому розрізі найбільше води забрано у басейні Дніпра 7365 млн м², Сіверського Дінця - 1448 млн м², Південного Бугу - 279,2 млн м ${ }^{3}$, Дністра 468,9 млн м ${ }^{3}$, Дунаю - 747,3 млн м ${ }^{3}$ та басейну Приазов'я - 499,5 млн м ${ }^{3}$ [15].

У галузевому розрізі у 2019 році основними водоспоживачами були підприємства сільського господарства, якими забирається 4380 млн м ${ }^{3}$ води або 39,42\% загального забору по країні (у т. ч. найбільші 3 них - зрошувальні системи 3727 млн м ${ }^{3}$, , промислові об'єкти - 4277 млн м ${ }^{3}$ води $\quad(38,49 \%, \quad$ у т. ч. найбільші 3 них: теплоелектростанції, атомні електростанції, підприємства чорної металургії та вугільної промисловості), комунального господарства 2411 млн м ${ }^{3}$ води $(21,70 \%)$, та інших галузей 43 млн м ${ }^{3}$ води $(0,39 \%)$ (рис. 3). У цілому використання прісної води у 2019 році на різні потреби становило 6821 млн $\mathbf{m}^{3}$ з них питної 1675 млн м $^{3}$ та технічної - 5146 млн м ${ }^{3}$, 469,4 млн м ${ }^{3}$ води питної якості використано на виробничі потреби, 3 них 141,7 млн м ${ }^{3}$ iз комунальних водопроводів (тобто, води, спеціально підготовленої до питної якості). У 2019 році використано 337,8 млн м ${ }^{3}$ стічних вод, 90,44 млн м ${ }^{3}$ колекторно-дренажних вод та 46,32 млн м ${ }^{3}$ шахтно-кар'єрних вод. У системах оборотного та повторно-послідовного водопостачання налічувалось 34074 млн м³ води. Втрати при транспортуванні на власні потреби (сукупність усіх видів витоків при виробництві, транспортуванні та постачанні питної води, в тому числі явних та невиявлених, а також необлікованих втрат води) склали 1119 млн м ${ }^{3}$ води (10,07 \% забраної). Більше половини обсягів води, які втрачаються, припадає на житловокомунальну галузь (760,6 млн м ${ }^{3}$ води, або $67,97 \%$ усіх втрат). Більшість води, яка втрачається у житлово-комунальній галузі, вже підготовлена для споживання [15].

За результатами узагальнення даних державного обліку водокористування у 2019 році у поверхневі водні об'єкти скинуто 5374 млн м ${ }^{3}$ стічних вод, у тому числі: підприємствами промисловості - 3478 млн м ${ }^{3}, \quad$ житловокомунальної галузі- 1473 млн м ${ }^{3} \quad$ та підприємствами сільського господарства 373,1 млн м ${ }^{3}$ (рис. 4) [15].

Із загального обсягу скинутих у водні об'єкти стічних вод забруднені складають 737,2 млн м ${ }^{3}$ (13,72\%), нормативно очищені 1188 млн м ${ }^{3}(22,11 \%)$, нормативно чисті без очистки - 3285 млн м ${ }^{3}(61,13 \%)$ та шахтнокар'єрні води, що не категорізуються 164,3 млн м ${ }^{3}(3,06 \%)$ [15]. 


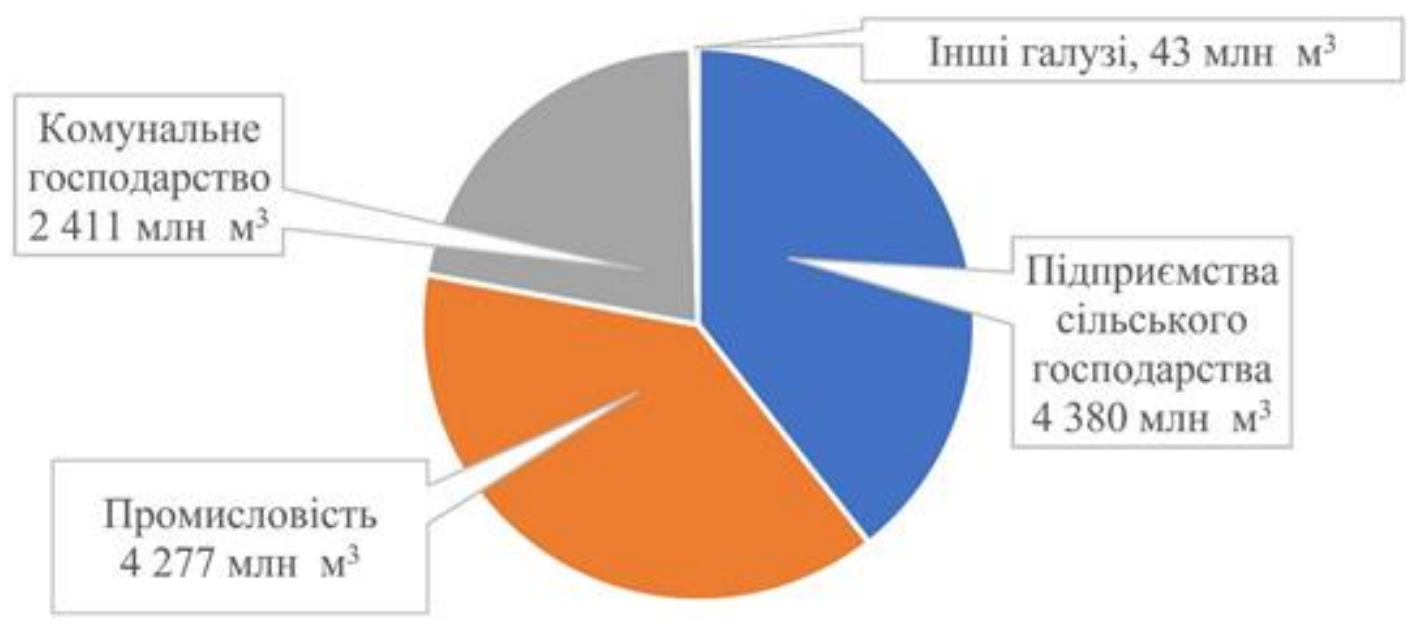

Рис. 3. Структура споживання води в Україні за галузями у 2019 році (загальний водозабір) [15]

Fig. 3. Structure of Water Consumption in Ukraine by Industry in 2019 (Total water intake) [15]

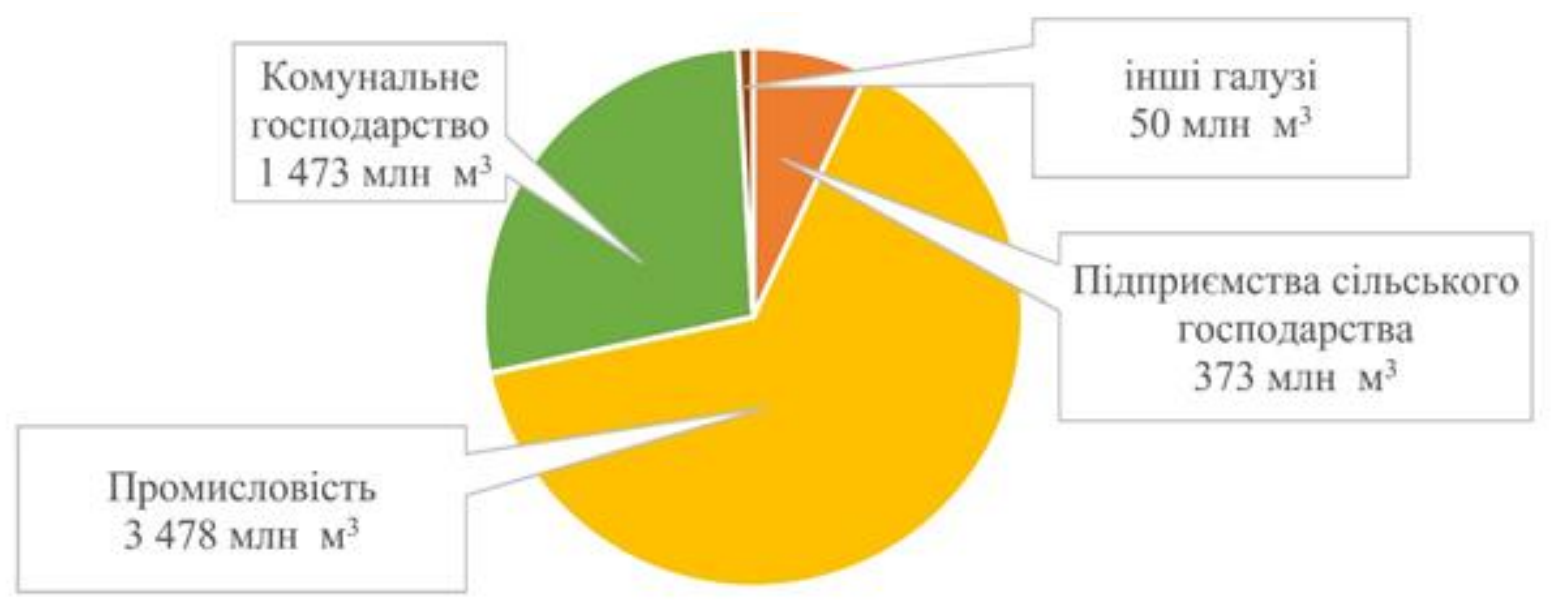

Рис. 4. Структура зливу стічних вод в Україні за галузями у 2019 році [15]

Fig. 4. The Structure of Sewage Discharge in Ukraine by Industry in 2019 [15]

Станом на 2019 рік втрати й витрати води становили 908,4 млн м 3 , 3 них 690,16 млн м³ - у системах централізованого водопостачання [15]. В табл. 1 наведено дані щодо втрат і витрат води в мільйонах кубічних метрів та у відсотках відносно кількості забраної води по областях. Найбільші кількісні втрати води зафіксовані в Донецькій (2018,3 млн м $\left.{ }^{3}\right)$, Дніпропетровській (119,9 млн м³) та Харківській $(92,4$ млн м³) областях. Найбільші відносні втрати води - у Чернівецькій $(61,8 \%)$, Закарпатській (50,7 \%), Житомирській $(49,8$ \%) та
Донецькій (49,5 \%) областях. У середньому по всіх регіонах (крім АР Крим) цей показник становить $36,4 \%$ (табл. 1).

Тобто впродовж року через зношеність мереж і обладнання, застарілі технології та з ряду об'єктивних причин (відкритість каналів для зрошення, аварії та прориви тощо) країна втрачає в 1,2 раза більше води, ніж потрібно для реалізації усього потенціалу «зеленого» водню.

Проте, відповідно до Наказу Міністерства регіонального розвитку, будівництва та житлово- 
комунального господарства України № 179 від 26.06.2014 «Про затвердження Порядку розроблення та затвердження технологічних нормативів використання питної води підприємствами, які надають послуги 3 централізованого водопостачання та/або водовідведення», перспективне значення втрат води (яке має бути досягнуте за рахунок удосконалення технологічних процесів підйому, виробництва й транспортування води в результаті впровадження енергоефективних технологій), до 2030 року має зменшитися до $150 \mathrm{~m}^{3}$ на $1000 \mathrm{~m}^{3}$ піднятої води (тобто 15 \%) [16].

Якщо взяти за вихідні дані кількість витраченої та втраченої води за 2019 рік, то зниження втрат до $15 \%$ приведе до економії 518 млн м ${ }^{3}$ води щороку, що становить майже $70 \%$ загальної кількості води, необхідної для реалізації всього потенціалу «зеленого» водню в Україні (табл. 1, рис. 5).

Щороку в Україні використовується близько 500 млн м ${ }^{3}$ морської води переважно для виробничих процесів підприємств чорної металургії [17], але вона цілком могла б застосовуватися для виробництва водню. А в контексті глобальних кліматичних змін та постійного i невідворотного підняття рівня світового океану, можливість вичерпаності цього ресурсу не вбачається загрозливою [10].

\section{Втрати та витрати води (станом на 2019 р.) \\ Нормативно-очищені стічні води (станом на 2019 p.) \\ Нормативно-чисті без очистки стічні води (станом на 2019 р.)
Економія води за рахунок зменшення втрат до $15 \%$ \\ На виробництво 505132 млн н м куб./рік "зеленого" водню потрібно води}

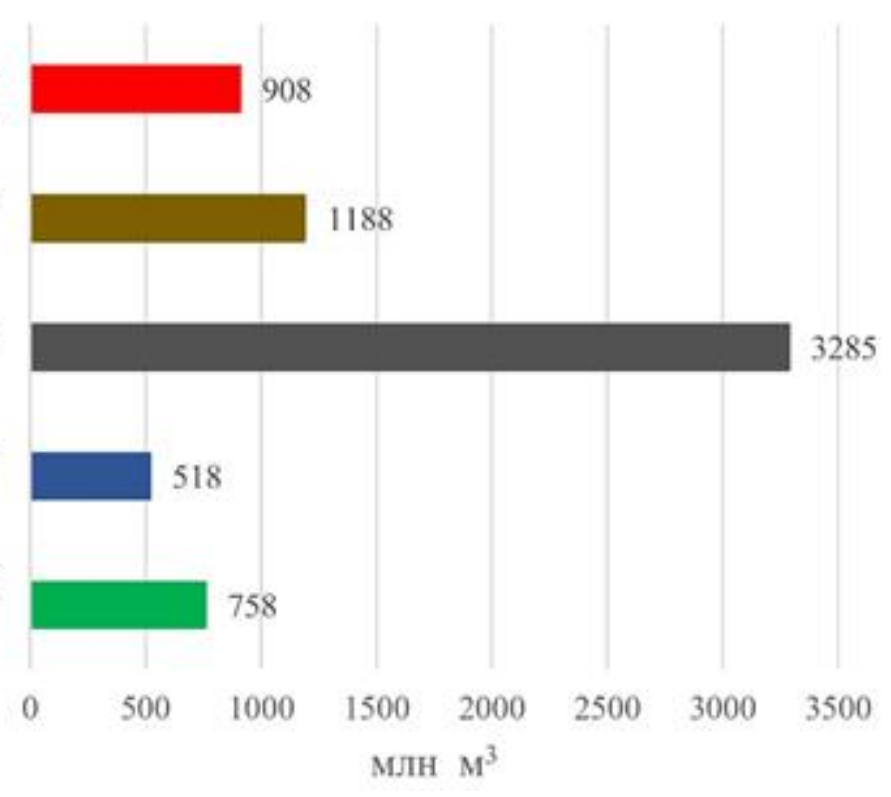

Рис. 5. Водні ресурси для виробництва «зеленого» водню

Fig. 5. Water resources for the "green" hydrogen production

Крім того, ресурсом для виробництва водню могли б слугувати нормативно очищені та нормативно чисті без очистки стічні води, сумарний обсяг яких впродовж 2019 року становив 4473 млн м ${ }^{3}$, що майже в 6 разів більше, ніж потрібно для реалізації всього потенціалу «зеленого» водню (рис. 5). 
Таблиця 1. Водокористування (потреби, витрати й втрати) за регіонами

Table 1. Water use (needs, expenses and losses) by region

\begin{tabular}{|c|c|c|c|c|c|c|c|}
\hline Область & $\begin{array}{c}\text { Потенціал } \\
\text { виробництва } \\
\text { «зеленого» водню, } \\
(4,5 \text { кВт·год на } \\
\left.1 \text { нм }^{3} \mathbf{H}_{2}\right), \\
\text { млн нм } / \text { рік }\end{array}$ & $\begin{array}{c}\text { Витрати } \\
\text { води на } \\
\text { виро- } \\
\text { бництво } \\
\text { «зеленого» } \\
\text { водню } \\
(1,5 \text { л на } \\
\left.1 \text { нм } \mathbf{H}_{2}\right), \\
\text { млн м³ }^{3}\end{array}$ & $\begin{array}{c}\text { Річне } \\
\text { викори- } \\
\text { стання води у } \\
\text { регіоні (дані } \\
2019 \text { р.), } \\
\text { млн м } \\
\end{array}$ & $\begin{array}{c}\text { Втрати й } \\
\text { витрати } \\
\text { води (дані } \\
2019 \text { р.), } \\
\text { млн м }\end{array}$ & $\begin{array}{c}\text { Втрати } \\
\text { води } \\
\text { (дані } \\
2019 \text { р.), } \\
\text { \% }\end{array}$ & $\begin{array}{c}\text { Прогно- } \\
\text { зовані } \\
\text { втрати води } \\
\text { при } \\
\text { плановому } \\
\text { зниженні } \\
\text { втрат до } \\
15 \%, \\
\text { млн м }\end{array}$ & $\begin{array}{c}\text { Економія } \\
\text { води за } \\
\text { рахунок } \\
\text { зменше- } \\
\text { ння втрат, } \\
\text { млн м }\end{array}$ \\
\hline $\begin{array}{c}\text { Автономна } \\
\text { Республіка Крим }\end{array}$ & 14314 & 21,5 & $\begin{array}{l}\text { немає } \\
\text { даних }\end{array}$ & $\begin{array}{l}\text { немає } \\
\text { даних }\end{array}$ & $\begin{array}{l}\text { немає } \\
\text { даних }\end{array}$ & $\begin{array}{l}\text { немає } \\
\text { даних }\end{array}$ & $\begin{array}{l}\text { немає } \\
\text { даних }\end{array}$ \\
\hline Вінницька & 9055 & 13,6 & 87,2 & 16,7 & 38,3 & 6,5 & 10,2 \\
\hline Волинська & 5074 & 7,6 & 53,5 & 9,4 & 35,8 & 3,9 & 5,5 \\
\hline Дніпропетровська & 24692 & 37,0 & 338,2 & 119,9 & 32,8 & 54,8 & 65,1 \\
\hline Донецька & 20516 & 30,8 & 1251,2 & 218,3 & 49,5 & 66,1 & 152,1 \\
\hline Житомирська & 7515 & 11,3 & 27,1 & 20,3 & 49,8 & 6,1 & 14,2 \\
\hline Закарпатська & 1170 & 1,8 & 29,5 & 11,6 & 50,7 & 3,4 & 8,1 \\
\hline Запорізька & 21029 & 31,5 & 1133,0 & 42,3 & 34,9 & 18,2 & 24,1 \\
\hline Івано-Франківська & 1968 & 3,0 & 81,5 & 13,7 & 43,6 & 4,7 & 9,0 \\
\hline Київська & 8263 & 12,4 & 512,5 & 84,7 & 16,6 & 76,5 & 8,2 \\
\hline Кіровоградська & 13711 & 20,6 & 45,8 & 13,6 & 42,2 & 4,8 & 8,7 \\
\hline Луганська & 20646 & 31,0 & 57,8 & 18,4 & 29,8 & 9,3 & 9,1 \\
\hline Львівська & 5637 & 8,5 & 122,3 & 49,3 & 42,5 & 17,4 & 31,9 \\
\hline Миколаївська & 19032 & 285 & 175,3 & 30,2 & 41 & 11,0 & 19,2 \\
\hline Одеська & 22173 & 333 & 318,5 & 61,9 & 35,2 & 26,4 & 35,5 \\
\hline Полтавська & 9818 & 147 & 84,0 & 27,5 & 43,2 & 9,5 & 17,9 \\
\hline Рівненська & 5409 & 8,1 & 96,2 & 7,0 & 27,7 & 3,8 & 3,2 \\
\hline Сумська & 7570 & 11,4 & 61,0 & 9,6 & 27,5 & 5,2 & 4,4 \\
\hline Тернопільська & 4721 & 7,1 & 40,2 & 5,2 & 26,6 & 2,9 & 2,3 \\
\hline Харківська & 17517 & 26,3 & 258,4 & 92,4 & 42,1 & 32,9 & 59,5 \\
\hline Херсонська & 22021 & 33,0 & 993,0 & 10,7 & 24,8 & 6,5 & 4,2 \\
\hline Хмельницька & 7051 & 10,6 & 63,9 & 11,8 & 28,2 & 6,3 & 5,5 \\
\hline Черкаська & 7138 & 10,7 & 149,7 & 11,4 & 30,3 & 5,6 & 5,8 \\
\hline Чернівецька & 1753 & 2,6 & 49,2 & 17,3 & 61,8 & 4,2 & 13,1 \\
\hline Чернігівська & 8598 & 12,9 & 89,6 & 5,4 & 19,4 & 4,2 & 1,2 \\
\hline $\begin{array}{c}\text { Територіальні } \\
\text { води та внутрішні } \\
\text { водойми } \\
\end{array}$ & 218742 & 328,1 & & & & & \\
\hline Загалом & 505132 & 757,7 & 6118,7 & 908,4 & & 390,5 & 517,9 \\
\hline
\end{tabular}

* без урахування даних водокористувачів тимчасово окупованих територій у Донецькій та Луганській областях, Автономній Республіці Крим та місті Севастополі

Висновки. У результаті проведених досліджень, встановлено, що Україна має високий середньорічний технічний потенціал виробництва зеленого водню - 505132 млн н м $3 /$ рік, що забезпечило участь України в європейській програмі “2x40 GW Green Hydrogen Initiative”, відповідно до якої в Україні буде встановлено
10 ГВт нових потужностей електролізерів для виробництва "зеленого" водню. Вказана ініціатива передбачає встановлення 2 ГВт нових потужностей електролізерів для внутрішнього ринку i 8 ГВт - для експорту водню трубопроводами до ЄС. Для середньорічного виробництва зеленого водню потрібно 
757,7 млн м $\mathbf{m}^{3}$ води. За загальним об'ємом відновлюваних водних ресурсів Україна посідає 56 місце у світі 3 показником 139,5 км³ [7]. Відповідно до даної оцінки, у використанні всього потенціалу виробництва "зеленого" водню (для якого потрібно 0,758 км ${ }^{3}$ води) було б задіяно 0,54\% загальних відновлюваних водних ресурсів. За умови водного дефіциту не видається доцільним збільшувати забір води заради виробництва водню, однак встановлено, що прогнозоване до 2030 року зменшення втрат води $\left(518\right.$ млн $\left.\mathbf{~ м}^{3}\right)$ за рахунок удосконалення технологічних процесів підйому, виробництва та транспортування води у результаті впровадження енергоефективних технологій, дозволяє на $70 \%$ задовольнити потребу у воді для використання всього наявного потенціалу виробництва «зеленого» водню.

Аналіз показав, що запаси нормативно очищених та нормативно чистих без очистки стічних вод (4473 млн м³) у 6 разів перевищують потребу для реалізації всього потенціалу «зеленого» водню.

Також для виробництва водню може бути використана морська вода, запас якої в контексті виробництва «зеленого» водню можна вважати практично невичерпним.

Отже, наявні водні ресурси України є цілком достатніми для повної реалізації потенціалу виробництва «зеленого» водню без збільшення водозабору.

1. Advanced Hydrogen Solutions. [Електронний pecypc]. URL: https://pdf.directindustry.com/pdf/hydrogenics/hy stat-hydrogen-generators/33492-420313-_7.html (дата звернення: 04.05.2021).

2. Hydrogen Generation Market by Application (Petroleum Refinery, Ammonia \& Methanol production, Transportation, Power Generation), Generation \& Delivery Mode (Captive, Merchant), Source (Blue, Green \& Grey Hydrogen), Technology, and Region-Forecast to 2025. [Електронний pecypc]. URL: https://www.marketsandmarkets.com/MarketReports/hydrogen-generation-market494.html?gclid=Cj0KCQiAqNPyBRCjARIsAKAWFzCRkG4KLggbSe31PM7vKSFH7STSqqo6OTLZWvAUpZXEArtVALFn4aAiH4EALw_wcB (дата звернення: 04.05.2021)

3. Kudria S., Ivanchenko I., Tuchynskyi B., Petrenko K., Karmazin $O$, Riepkin $O$. Resource potential for wind-hydrogen power in Ukraine, International Journal of Hydrogen Energy. 2021. № 46 (1). Pp. 157-168.

https://doi.org/10.1016/j.ijhydene.2020.09.211

4. Proportion of Total Water Resources Used, percentage. [Електронний pecypc]. URL: http://chartsbin.com/view/1473 (дата звернення: 04.05.2021).

5. Renewable internal freshwater resources per capita (cubic meters) - Country Ranking. [Електронний pecypc]. URL: https://www.indexmundi.com/facts/indicators/ER.H2O.INTR.PC /rankings (дата звернення: 04.05.2021).

6. Total Renewable Water Resources per capita by Country. [Електронний ресурс]. URL:

http://chartsbin.com/view/1470 (дата звернення: 04.05.2021).

7. Total renewable water resources. [Електронний pecypc]. URL: http://chartsbin.com/view/1469 (дата звернення: 04.05.2021).

8. Атлас енергетичного потенціалу відновлюваних джерел енергії України. За ред. С.О. Кудрі. Київ. Інститут відновлюваної енергетики НАН України. 2020. 82 с.

9. Відновлювані джерела енергії. За заг. ред. С.О. Кудрі. Київ. Інститут відновлюваної енергетики НАНУ. 2020. 392 c.

10. Вода близько. Підвищення рівня моря в Україні внаслідок зміни клімату. [Електронний ресурс]. URL: https://mepr.gov.ua/files/docs/Zmina klimaty/2020/voda blyzko report full-c.pdf (дата звернення: 04.05.2021).

11. Водний кодекс України. [Електронний ресурс]. URL: https://zakon.rada.gov.ua/laws/show/213/95-

\%D0\%B2\%D1\%80 (дата звернення: 04.05.2021).

12. Водні ресурси України. [Електронний ресурс]. URL: http://www.nbuv.gov.ua/node/3972 (дата звернення: 04.05.2021).

13. Інформація про об'єкти альтернативної енергетики, яким встановлено "зелений" тариф. [Електронний ресурс].

URL: http://www.nerc.gov.ua/data/filearch/elektro/energo_pidpr yemstva/stat_info_zelenyi_taryf/2021/stat_zelenyi-taryf.2-

2021.xlsx (дата звернення: 04.05.2021).

14.Кудря С.О., Іванченко І.В., Петренко К.В., Кармазін О.О., Антон А.О., Репкін О.О. Вартість виробництва водню за допомогою електролізу. Матеріали XXII Міжнародної науково-практичної конференції «Відновлювана енергетика та енергоефективність». Київ. 2021 травня 2021 р. К. Інтерсервіс. 2021. С. 329-334.

15. Національна доповідь про якість питної води та стан питного водопостачання України в 2019 р. [Електронний pecypc]. URL: https://www.minregion.gov.ua/wpcontent/uploads/2020/11/proekt-nacz.-dop.-za-2019.pdf (дата звернення: 04.05.2021).

16. Порядок розроблення та затвердження технологічних нормативів використання питної води підприємствами, які надають послуги 3 централізованого водопостачання та/або водовідведення. [Електронний pecypc]. URL: https://zakon.rada.gov.ua/laws/show/z106214\#n21 (дата звернення: 04.05.2021).

17. Сучасне
ронний ресурс]

[Електронний ресурс]. 
URL: https://www.davr.gov.ua/news/suchasnevodokoristuvannya-ukraini (дата звернення: 04.05.2021).
18. Хільчевський
B.K.
Водопостачання

водовідведення: гідроекологічні аспекти. Підручник. К. ВПЦ «Київський університет». 1999. 319 с.

\section{REFERENCES}

1. Advanced Hydrogen Solutions. [Electronic resource]. URL: https://pdf.directindustry.com/pdf/hydrogenics/hystathydrogen-generators/33492-420313-_7.html (Applying date: 04.05.2021). [in English].

2. Hydrogen Generation Market by Application (Petroleum Refinery, Ammonia \& Methanol production, Transportation, Power Generation), Generation \& Delivery Mode (Captive, Merchant), Source (Blue, Green \& Grey Hydrogen), Technology, and Region-Forecast to 2025. [Electronic resource]. URL: https://www.marketsandmarkets.com/MarketReports/hydrogen-generation-market494.html?gclid=Cj0KCQiAqNPyBRCjARIsAKAWFzCRkG4KLggbSe31PM7vKSFH7STSqqo6OTLZWvAUpZXEArtVALFn4aAiH4EALw_wcB (Applying date: 04.05.2021). [in English].

3. Kudria S., Ivanchenko I., Tuchynskyi B., Petrenko K., Karmazin $O$, Riepkin $O$. Resource potential for wind-hydrogen power in Ukraine, International Journal of Hydrogen Energy. 2021. No. 46 (1). Pp. 157-168.

https://doi.org/10.1016/j.ijhydene.2020.09.211. [in English].

4. Proportion of Total Water Resources Used, percentage. [Electronic resource].

URL: http://chartsbin.com/view/1473 (Applying date: 04.05.2021). [in English].

5. Renewable internal freshwater resources per capita (cubic meters) - Country Ranking. [Electronic resource]. URL: https://www.indexmundi.com/facts/indicators/ER.H2O.INTR.PC /rankings (Applying date: 04.05.2021). [in English].

6. Total Renewable Water Resources per capita by Country. [Electronic resource].

URL: http://chartsbin.com/view/1470 (Applying date: 04.05.2021). [in English].

7. Total renewable water resources. [Electronic resource]. URL: http://chartsbin.com/view/1469 ( Applying date: 04.05.2021). [in English].

8. Atlas enerhetychnoho potentsialu vidnovliuvanykh dzherel enerhii Ukrainy. [Atlas of energy potential of renewable energy sources of Ukraine]. For order. S.O. Kudri. Kiev. Institute of Renewable Energy of the National Academy of Sciences of Ukraine. 2020. 82 p. [in Ukrainian].

9. Vidnovliuvani dzherela enerhii. [Renewable energy sources]. For the general ed. S.O. Kudri. Kiev. Institute of Renewable Energy of NASU. 2020.392 p. [in Ukrainian].
10. Voda blyzko. Pidvyshchennia rivnia moria v Ukraini vnaslidok zminy klimatu. [Water is close. Sea level rise in Ukraine due to climate change.]. [Electronic resource]. URL: https://mepr.gov.ua/files/docs/Zmina_klimaty/2020/voda_blyzko _report_full-c.pdf (Applying date: 04.05.2021). [in Ukrainian].

11. Vodnyi kodeks Ukrainy. [Water Code of Ukraine]. [Electronic resource]. URL: https://zakon.rada.gov.ua/laws/show 1213/95-\%D0\%B2\%D1\%80 (data zvernennia: 04.05.2021). [in Ukrainian].

12. Vodni resursy Ukrainy. [Water resources of Ukraine]. [Electronic resource]. URL: http://www.nbuv.gov.ua/node/3972 (Applying date: 04.05.2021). [in Ukrainian].

13. Informatsiia pro obiekty alternatyvnoi enerhetyky, yakym vstanovleno "zelenyi" taryf. [Information on alternative energy facilities with a "green" tariff]. [Electronic resource]. URL: http://www.nerc.gov.ua/data/filearch/elektro/energo pidpr yemstva/stat info zelenyi taryf/2021/stat zelenyi-taryf.22021.xlsx (Applying date: 04.05.2021). [in Ukrainian].

14. Kudria S.O., Ivanchenko I.V., Petrenko K.V., Karmazin O.O., Anton A.O., Riepkin O.O. Vartist vyrobnytstva vodniu za dopomohoiu elektrolizu Materials of the XXII International Scientific and Practical Conference "Renewable Energy and Energy Efficiency". Kiev. May 20-21. 2021. K. Interservice. 2021. Pp. 329-334. [in Ukrainian].

15. Natsionalna dopovid pro yakist pytnoi vody ta stan pytnoho vodopostachannia Ukrainy v 2019 r. [National report on the quality of drinking water and the state of drinking water supply in Ukraine in 2019]. [Electronic resource].

URL: https://www.minregion.gov.ua/wpcontent/uploads/2020/11/proekt-nacz.-dop.-za-2019.pdf

(Applying date: 04.05.2021). [in Ukrainian].

16. Poriadok rozroblennia ta zatverdzhennia tekhnolohichnykh normatyviv vykorystannia pytnoi vody pidpryiemstvamy, yaki nadaiut posluhy $\mathrm{z}$ tsentralizovanoho vodopostachannia ta/abo vodovidvedennia. [The procedure for development and approval of technological standards for the use of drinking water by enterprises that provide services for centralized water supply and/or drainage.].

URL: https://zakon.rada.gov.ua/laws/show/z1062-14\#n21

(Applying date: 04.05.2021). [in Ukrainian].

17. Suchasne vodokorystuvannia Ukrainy. [Modern water use in Ukraine.]. [Electronic resource].

URL: https://www.davr.gov.ua/news/suchasne-

vodokoristuvannya-ukraini (Applying date: 04.05.2021). [in Ukrainian].

18. Khilchevskyi V.K. Vodopostachannia i vodovidvedennia: hidroekolohichni aspekty. Water supply and drainage: hydroecological aspects. Textbook. K. VPC "Kyiv University". 1999. 319 p. [in Ukrainian].

Стаття надійшла до редакції 06.05.21 Остаточна версія 17.06.21 